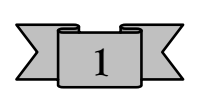

\title{
Cultivating an Attitude of Professionalism Based on Prophetic Value
}

\author{
*Yeni Rosilawati ${ }^{1}$, Faisal Muhammad Amanullah ${ }^{2}$ \\ 1,2(Universitas Muhammadiyah Yogyakarta, Jl. Brawijaya, DIY, Indonesia) \\ *yenirosilawati@gmail.com
}

\begin{abstract}
Professionalism is a matter of attitude towards the values that apply in the world of work. Professionalism is a condition or attitude manifested by individuals in carrying out their duties. In its implementation, it requires individual expertise as a result of learning from specific education or training. However, in today's reality, the Indonesian people have not put forward the values of professionalism in every work activity. So what happens is that various cases such as corruption and fraud occur. This study aims to analyze the attitude of professionalism and its relationship with prophetic values. This study uses qualitative research methods with data collection techniques through literature study. Qualitative research is a way of analysis to understand the meaning behind individuals or groups in personal or social problems. The research data were taken from various books, journals, and news articles to provide data on professional attitudes and prophetic values. The researcher analyses and interprets the collected data as a reference and answer to the existing problems. The results show that in Islam, professionalism has been regulated by referring to prophetic values. Prophetic values are values that exist in the Prophet Muhammad SAW. Prophetic values are the values of professionalism that are directly actualized by the Prophet Muhammad. With these values, he gained a lot of public trust at that time. These values that Indonesian people should implement today in every daily activity and the world of work.
\end{abstract}

Keywords: Professionalism, Indonesian Reality, Prophetic Value.

\section{Introduction}

A country can be advanced when its people can respect the ethics that apply in the social order. Indonesia is a country that has ethical religions spread over 34 provinces. Each region has different ethics in society, like the term unggah-ungguh in Javanese tradition, which means respect. Frans Magnis Susenon explained that uploading is synonymous with the principle of care, which is an attitude in which a person speaks and carries themself always or has to show respect to 
others (Suseno, 1985). The Javanese people will more readily accept someone who is used to it.

Likewise, in the world of work, there is an attitude that everyone must consider. If one wants to survive in position, then everyone must conform to the prevailing values. They cannot work as they please (Anwar, 2021). In terms of the world of work, a professional attitude becomes a person's assessment at work. Professional that is seen first is a matter of perspective and then several other things that are considered to represent a professional attitude such as work skills, and work performance (Harefa, 2004). This attitude then becomes a person's assessment at work.

Someone who can carry out his professional attitude can survive in work because of this attitude. However, someone who has not been able to carry out his professional attitude will not last long in the world of work. Experienced people are relied on and trusted because they are experts, skilled, have the knowledge, are responsible, diligent, full of discipline, and have seriousness in carrying out their work duties (Putri \& Heriyudanta, 2021). Therefore, the term professional is always synonymous with ability, knowledge or education and independence (Meister, 1998). Thus, a professional attitude is very concerned about self-quality, personal interests and prioritizing common interests for work.

As for seeing someone who is professional, some characteristics describe a professional attitude. The elements are as follows:

1. Having skills or abilities, high knowledge that is not possessed by other people in general (education, training and experience).

2. Have a code of ethics and is a moral standard for the profession. A code of ethics is a standard or moral commitment.

3. Have professional responsibility and personal integrity.

4. Have a spirit of service to the public or society. Putting personal interests for the sake of society, nation and state.

The explanation above can at least describe a professional in general. Although in practice, not a few people ignore this attitude. In fact, through this attitude, a person will be assessed for the quality of work based on the professional attitude.

As explained above how a professional attitude needs to be instilled in every person who works. Indonesia will never become a developed country because of its people who have not prioritised applicable ethics, both in society in general and more specifically in 
the world of work. When you look at the reality in Indonesia today, it is very natural that Indonesia will not become a developed country. The crisis of attitude is the lack of awareness of Indonesians. The problem occurs because they do not have a personal commitment to be responsible for their work. They have not been able to position themselves against private interests and work interests in carrying out their duties.

For example, the leadership problem that occurred in Indonesia. Cases of corruption that ensnared regional heads. In the last 13 years, from 2005-2018, the number of regional authorities caught in corruption cases reached 56 regional leaders captured by the Corruption Eradication Commission (KPK). Degradation of attitude occurs when they forget that they become regional heads by the people's choice. They should prioritize the interests of the people, not the other way around who prioritizes personal interests by taking advantage of their positions to enrich themselves (Gerintya, 2018).

The next issue that occurs is related to discipline. Indonesians who are trusted to become Civil Servants (PNS) still ignore the penalty of time. Especially about attendance after a long holiday. In some areas, many civil servants are late for the first day of work. This happened in DKI Jakarta. As many as 1,081 civil servants were late for work on the first day after vacation. Time delay has become a culture every year. They forget that their daily life is the result of state money. The amount of time given is still considered insufficient. The effect is neglected work interests (Priyasmoro, 2018).

The case above is an example of the many problems of Indonesian people who work but have not instilled a professional attitude in themselves. The commitment to make work a common interest is still ignored for various reasons of personal interest. The attitude to the above case is that Indonesian people do not have a role model for them in their work. Islam has described a figure who becomes a role model for his personality, who places himself as an individual and responsible for the trust that others have given.

The term professionalism is based on a combination of the words profession and professional. According to the Big Indonesian Dictionary (Badan Pengembangan dan Pembinaan Bahasa, 2015), profession means a field of work based on specific skill education, while professional means people involved or meet qualifications in a profession. Professionalism can be interpreted as quality, quality, and behaviour that characterise a professional or professional person. 
Professionalism is defined as the character shown by each individual in behaving and in a goal when carrying out his work or profession (Suwinardi, 2017). This character will lead the individual to provide the best quality of his work when he is working. Meanwhile, another meaning of professionalism is also explained as the expertise or reliability of an individual in carrying out his work or duties so that the assignment or task is carried out with high quality, on-time, carefully, and all procedures he does can be understood and followed by customers easily (Siagian, 2009a).

Sedarmayanti also expresses another meaning of professionalism. According to him, professionalism is a condition or attitude manifested by individuals in carrying out their duties which in its implementation requires individual expertise as a result of learning from specific education or training (Sedarmayanti, 2004). In addition, the meaning of professionalism is also explained by Atmosoeprapto in (Kurniawan, 2005), professionalism can be interpreted as a reflection of competence, which consists of knowledge, skills, abilities, all of which are also supported by experience over time by each individual.

Sondang P. Siagian, in his book entitled "Tips to Increase Work Productivity", describes several indicators of professionalism consisting of ability, quality, facilities and infrastructure, number of human resources, information technology, and reliability (Siagian, 2009b). 1) Ability. This indicator relates to individual skills or potentials in mastering a particular skill, either from birth or training or practice. 2) Quality. This indicator relates to the dynamism between aspects of products, services, people, processes, and the environment that must be interwoven to meet or exceed expectations. 3) Facilities and infrastructure. This indicator relates to a set of tools, both leading equipment and supporting equipment, that assist the process of activities or completion of work. 4) Number of HR. This indicator relates to each worker's potential, skills, or abilities in an organization or company. The potential possessed by each individual serves to support the running of the organization or company. 5) Information Technology. This indicator relates to a set of tools that serve to assist workers in matters or tasks related to information processing. 6) Reliability. This indicator relates to the consistency of a series of measuring instruments or measurements that can be in the form of measurements from the same measuring instrument (test with retest) to show the same results.

Suwinardi, in the journal article "Professionalism at Work", describes several characteristics of professionalism (Suwinardi, 2017), 
namely 1) Professionalism is related to the nature that is focused on the perfection of the work (perfect result), which makes individuals required to improve quality continuously. 2) Professionalism requires work accuracy and sincerity from each individual, obtained from habits and experience from work. 3) Professionalism encourages each individual to be diligent and steadfast. This relates to the nature of not being easily discouraged or satisfied until the expected results are achieved. 4) Professionalism requires high integrity that is not easily shaken from coercion or the temptation of faith, such as enjoyment of life or wealth. 5) Professionalism requires unanimity of thoughts and actions to maintain high work effectiveness.

Suwinardi also explained some of the components needed to carry out professional competence (Suwinardi, 2017), namely 1) Individual competence, which consists of initiative, trustworthiness, motivation, and creativity. 2) Social competence consisting of communication, cooperation and group work. 3) Methodical competence consists of competence in gathering information and analyzing the information. This competency also includes evaluating information, orienting work goals, and working systematically. 4) Specialist competence consists of skills and knowledge, ideally using equipment or work tools, organizing and solving problems.

Martin Jr describes another aspect of professionalism in Kurniawan, which contains the professional characteristics of the apparatus (Kurniawan, 2005). These characteristics are 1) Equality (equality or similarity), namely providing the same treatment or service. 2) Equity, namely providing fair and equal treatment. 3) Loyalty, namely showing loyalty to the legal constitution, leaders, coworkers, and subordinates. 4) Accountability, namely readiness to accept or take responsibility for everything he does. Apparatus is required to adhere to the code of ethics and principles that have been established and apply in the institution (Tamrin, Rumapea, \& Mambo, 2017).

In Islam, working for a Muslim is an earnest effort, by mobilizing all his assets, thoughts, and dhikr to actualize and reflect his meaning as a servant of Allah who must subdue the world and place himself as part of the best society (khoiru ummah). Or in other words, it can be said that only by working humans humanize themselves (Tasmara, 2002).

Islam provides a prophetic figure (prophet) who becomes an example for every human being carrying out his life. Allah SWT created Prophet Muhammad SAW. like humans in general. However, 
Allah has given an ideal person who can place a good position as an individual (servant of Allah), family leader, national leader, and Muslim leader. The Prophet Muhammad SAW carried out every mandate with a complete sense of responsibility by separating personal interests from common interests. Because of his personality, Allah mentions in the Qur'an:

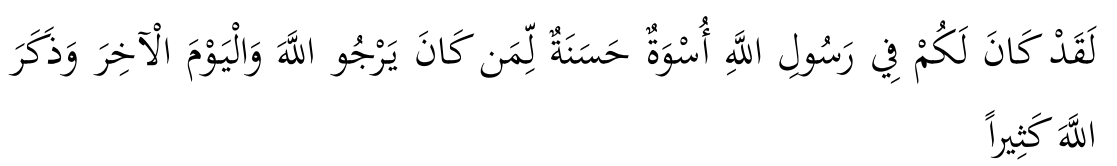

Verily there is in the Messenger of Allah a good role model for you (that is) for those who hope (the mercy of) Allah and (the coming of) the Day of Judgment and he mentions Allah a lot.(QS.33:21)

The word prophetic comes from the English word "prophet", which means prophet. According to the Oxford Dictionary, "prophetic" is (1) "Of, pertaining or proper to a prophet or prophecy"; "having the character or function of a prophet"; (2) "characterized by, containing, or of the nature of prophecy; predictive". Meanwhile, etymologically, prophetic means prophetic or "necromancer". According to Dagum in Roqib, the prophet can picture the future in this world and the hereafter (Roqib, 2013). In historical records, the prophets of Allah SWT. especially the prophet Muhammad SAW. recorded has given the success of the history of humanity. This makes him believe that if the things done and applied by the prophet are used as views or perspectives in building and developing social science to answer and solve human problems, and they will reap success.

The prophet is a human being with excellent character and exemplary character both physically and psychologically to communicate effectively with God and angels (Roqib, 2013). Some prophets have holy books revealed to them by Allah SWT as a guide and reference for their people. By Allah SWT., The prophet is prepared. It prepares him through an educational process in mental, spiritual, physical, and social training so that he is ready to pick up revelations from Allah SWT. The prophet also prepared himself through ideal physical potential, noble descent, and a formidable psychological condition. The superior possibilities possessed by the prophet will later form the nature of honesty or shiddiq, trust or responsibility, communicative or tabligh, and intelligence or fathonah. The four traits in this prophet make the prophets become figures or figures who are always guided by conscience and truth (conscience centre), maintain professionalism and commitment, master 
communication skills, and can solve problems (Roqib, 2013). So the prophetic meaning has the nature or characteristics of a prophet. From the word predictive itself, we can conclude that the values in question are predictive.

\section{Method}

This study uses qualitative research methods with data collection techniques through literature study. Qualitative research is a research strategy that emphasizes words rather than quantification in collecting and analyzing data (Bryman, 2012). Meanwhile, according to Creswell, qualitative research is a way of analysis to understand the meaning behind individuals or groups in personal or social problems (Creswell, 2009). Through data collection techniques based on literature study, the primary data were Al-Quran and Hadith. Meanwhile, secondary data or research supporting data for this study were taken from various books, journals, and news articles that we're able to provide data on professional attitudes and prophetic values. The collected data is analyzed and interpreted by the researcher as a reference and answer to the existing problems (Ikhwan, 2020).

\section{Result and Discussion}

Based on the findings of the researchers regarding the condition of the Indonesian people who have jobs but still have not instilled a professional attitude in themselves and their daily life, while there are professional and prophetic values as well as role models that the Indonesian people can emulate, the results of research and discussion regarding professionalism and prophetic values are as follows.

\section{Correlation of Professionalism Values with Prophetic Values}

In realizing someone who works professionally, someone needs to see the best example for humans on this earth as described above. Prophet Muhammad SAW had four qualities that he always did in every life. The four characteristics of the Prophet Muhammad SAW consist of Siddiq or honesty, Amanah or responsibility, Fathonah or intelligence, and Tabligh or communicative (Hidayahtullah, 2010):

\section{Shiddiq (Right)}

Shiddiq is defined as a truth reflected in his words, actions, and inner state. The nature of siddiq leads humans to always have an honest heart in every word and action. In this case, what is said will be 
in line with what is done (not lying). Through the nature of this shiddiq, Rasulullah SAW. given the title Al-Amin because every deed will always reflect what he has said. On various occasions, he always puts this shiddiq character first. Rasulullah SAW. Remind people to always be honest in every word and deed.

Rasulullah Sallallahu 'Alaihi Wasallam said:

"There are four things, whoever has these four things in himself then he becomes a true hypocrite, and if one of the characteristics of these four things is in himself, then in him there is one characteristic of hypocrisy until he abandons it: when he talks he always lies, if you make an agreement you break it, if you make a promise you always break it, and if you disagree, you are sly." (Narrated by Imam Muslim in the Interpretation of Amanah Verses in the Quran) (Abidin \& Khairudin, 2017).

2. Amanah (responsibility)

Amanah is the trust given by others that must be carried out in realizing something that is done with full responsibility, commitment, hard work, consistency and full of sincerity. Not a few people refuse to be given a mandate, knowing the weight that must be carried when the assignment is given. However, nowadays, not a few people are fighting over the trust. The trust has a heavy burden, those who carry out the mandate will not only be responsible to their fellow humans, but they will also be responsible to Allah SWT. about the extent to which the trust is implemented.

It was narrated from Abu Dzar that he said:

"O Messenger of Allah, why did you not give me a position? He said: "The Messenger of Allah. then put his hand on my shoulder and said: "O Abu Dharr you are weak, and the position is a trust, and indeed this position will be an insult and regret later on the Day of Resurrection, except for those who carry it seriously and fulfill it according to the rights contained in the position." (HR. Imam Muslim in Amanah) (Noor, n.d.).

\section{Fathonah (intelligent)}

Fathonah means someone who has intelligence, proficiency and mastery of specific fields, including intellectual, emotional, and spiritual intelligence. The nature of fathonah is described into several parts: 1) can adapt to the developments and changes of the times 2) has superior, quality, competitive competence 3) has intellectual, emotional and spiritual intelligence (Hidayahtullah, 2010). Therefore, 
in a person's work, one must know skills in the chosen field. Rasulullah SAW. Allah has blessed us with complete knowledge. However, he always thinks about learning something. Like when he made a strategy in the Battle of Badr.

His leadership, accompanied by intelligence and extraordinary leadership style, appears when he organizes, plans, and controls his troops when facing war. For example, during the Battle of Badr, he made preparations and good war strategies when facing the enemy so that the enemy suffered defeat (Tongkrongan Islami, 2017a).

\section{Tabligh (convey)}

Tabligh has the meaning of conveying all the words of Allah SWT. shown to humanity was given by the Prophet Muhammad SAW. In this case, the Messenger of Allah SWT. bears the title of mundhir (warner) by Allah SWT. The Prophet Muhammad was sent. As a person who gives the warning to guide people, improve and prepare humans to achieve happiness in this world and the hereafter. The Mundhir predicate that he carries requires him to lead his people and be tasked with delivering (tabligh) treatises to humans. The proof is when the Prophet Muhammad SAW. conveyed his greatest miracle, namely the Qur'an.

Evidence that the Prophet Muhammad. Tabligh has the character of an apostle, namely the revelation of the Qur'an as its greatest miracle to be conveyed to the ummah. At the beginning of his apostolate, the Prophet spread Islam in secret. But after gaining enough followers, the Prophet was ordered to preach openly. So that one day, the Prophet SAW. climbed to Mount Safa in Mecca, shouting, calling the Quraysh to declare themselves to worship Allah SWT. and leave idols and testify that Muhammad is His messenger. After their speech, the Quraysh insulted and said that Muhammad was a madman (Tongkrongan Islami, 2017b). The story describes that the Prophet Muhammad SAW. has started his mission as an apostle to preach to his people even though he received insults, insults but he still faced them with great patience.

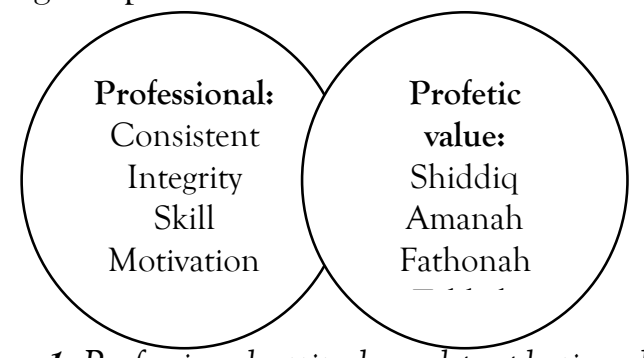

Figure 1. Professional attitude and prophetic values 
The four main characteristics of the Prophet Muhammad. If applied properly, it will form a figure with superior characteristics as well. Moh Roqib describes four characteristics resulting from the application of the four main characteristics of the Prophet Muhammad Saw (Roqib, 2013). namely:

1. A person who is always guided by conscience and truth. This person will not follow lust or be affected by adverse environmental conditions. Individuals who have applied prophetic values will practice and spread truth and human values to various circles of society.

2. A person who always maintains the quality of his professionalism and commitment. This person will do what he has said consequently, he will try to behave or implement something by the mandate he has received. This person will maintain the mandate or responsibility, primary duties, and functions properly so as not to fall into the temptation of lust to occupy positions or control wealth.

3. Individuals who have the skills to communicate with various groups and strata. When establishing communication, this person will not discriminate between ethnic groups, religions, political parties, and groups. Regardless of the classification, this person will always convey the truth and communicate to everyone to provide benefits and peace of life.

4. Individuals who can solve problems because of their multiintelligence abilities. This person has a vital role as a critical person who can solve various issues in his environment or society. This individual will make good use of the facilities and the environment, both physical and social, to encourage the achievement of noble goals for the community.

\section{Actualization of Professionalism Values Based on Prophetic Values}

In the end, the values of professionalism have been regulated in Islam along with an example of a living figure, namely the Prophet Muhammad. Although in practice, actualizing prophetic values is not as easy as imagined. At least the prophetic values in the Prophet Muhammad can be the basis of a person in carrying out his life, especially those related to a job (Ikhwan, 2019). In work, one must always present prophetic values in every form of activity. Thus, professional values based on prophetic values will bring someone to a job that is pleasing to Allah SWT. 
Several stories describe the figure of the Prophet Muhammad who was able to work professionally. Below are some of his stories: First, as explained above, Indonesia is currently in crisis for someone who works honestly, holds the people's trust with full responsibility, prioritizes common interests over personal interests and other forms of value crisis. For example, the corruption case that ensnared regional heads. In the last 13 years, starting from 2005-2018, the number of regional authorities caught in corruption cases reached 56 regional leaders who were seen by the KPK (Gerintya, 2018). Seeing this case proves that the Indonesian leaders, who the people elected to voice their every aspiration, are unable to fulfil their promises. Even those caught in the case are concerned with their interests by enriching themselves.

Therefore, the prophetic values that exist in the Prophet Muhammad SAW. it is appropriate to be an example for Indonesian leaders and workers today. The Prophet Muhammad at that time, apart from being the head of the family, the leader of the Muslims, was also the head of the state. In terms of finances, this time after the victory of the Badr war. There are spoils of war that are debatable where these treasures will be. After that, the verse about the spoils of war came down in Surah Al-Anfal, 8 verse 41. Through this verse, the Messenger of Allah. They founded Baitul Mall to manage the finances and property of the Muslims at that time. State financial matters were also submitted to the Baitul Mall. For every asset that comes in, the Messenger of Allah has the principle to distribute these assets to those entitled to it directly. Otherwise, the property will be spent for the public interest (Ab Rahmani, 2018). The management of Baitul Mall at that time was still not well managed, but it was improved when $\mathrm{Abu}$ Bakr became Caliph.

From the brief story above, it can be a lesson that the Prophet Muhammad did not like to accumulate wealth and finances, which were for the benefit of Muslims at that time. So that when the wealth and finances enter the country, the Messenger of Allah SWT. will distribute it directly to Muslims in need. Otherwise, he will spend the property for the common good. If today's Indonesian leader has the same principle as the Prophet SAW, at least the Indonesian people will no longer have difficulties fulfilling their daily needs.

Second, the case that occurred in Indonesia was a misused business (fraud). Like the case of First Travel, who deceived the Umrah pilgrims. A total of 63,310 Umrah pilgrims have paid in full to First Travel. However, in reality, they did not go to perform Umrah. The money 
that had been paid was blamed for being used by the boss of First Travel, so that they were charged with embezzlement and money laundering with a sentence of 20 years in prison (BBC News Indonesia, 2018). Even though the money was mandated by the travel party to take them to worship in the holy land, the irresponsible party no longer thinks about the fate of these people.

The above case may not have happened if they saw how the figure of the Prophet Muhammad saw. In fulfilling his life, Rasulullah SAW. also carry out their business by trading. When the conditions of the Arab society are ignorant. Rasulullah SAW. uphold the principle of honesty in its trading activities. Through this honesty in trading, he was trusted by a wealthy person in Mecca, namely Khadijah, to manage the merchandise. Because Khadijah knew that the Messenger of Allah was an honest person with buyers, and in each of his merchandise, he did not take advantage of himself personally. On that basis, Khadijah finally married the Messenger of Allah (Afzalurrahman, 2000). It is proper that the Indonesian people can maintain honesty in every business activity and their daily lives. This principle will bring someone in another unexpected sustenance.

The above reality is one of the professional value crises that is happening in Indonesia at this time, there are still other cases that illustrate the inability of the Indonesian people to work professionally in their work. Both those who work in the government and those who work as entrepreneurs, they all still prioritize their personal interests by taking inappropriate actions.

\section{Conclusion}

Indonesia has the opportunity to become a developed country, benefiting from a large number of human resources. This opportunity has not been able to be exploited by this nation. The concern of the Indonesian people to work professionally is still far from what is expected. Therefore, the professionals' values above correlate by looking at examples of life as someone successful in this world and the hereafter, namely the Prophet Muhammad. Through his qualities that are consistently applied in every daily activity and the world of work. Prophetic values are the values of professionalism that are directly actualized by the Prophet Muhammad. With these values, he gained a lot of public trust at that time.

Therefore, through this paper to all readers who will later face the world of work. Prophetic Values that have been exemplified by the 
Prophet Muhammad. in each of its activities has always been the principle of professionalism in work. With these values, all forms of goodness will return to each of us.

\section{Bibliography}

Ab Rahmani, A. (2018). Peranan Baitulmal dalam Pendidikan Asnaf: Kajian di Majlis Agama Islam Wilayah Persekutuan. Journal of Fatwa Management and Research. https://doi.org/10.33102/jfatwa.vol11no1.18

Abidin, Z., \& Khairudin, F. (2017). Penafsiran Ayat-Ayat Amanah Dalam Al-Qur'an. Jurnal Syahadah Vol., V(2), 120.

Afzalurrahman. (2000). Muhammad Sebagai Seorang Pedagang. Jakarta: Yayasan Swarna Bhumy.

Anwar, S. (2021). Pendidikan Karakter: Kajian Perspektif Tafsir fi Zilalil Qur'an. Tulungagung: STAI Muhammadiyah Tulungagung.

Badan Pengembangan dan Pembinaan Bahasa. (2015). Kamus Besar Bahasa Indonesia Online.

BBC News Indonesia. (2018). Dana umrah: Bos First Travel didakwa penggelapan dan pencucian uang.

Bryman, A. (2012). Social Research Methods (Fourth Edition). New York: Oxford University Press.

Creswell, J. W. (2009). Research Design, Qualitative, Quantitative and Mixed Methods Approaches. Thousand Oaks, California USA: Sage Publications.

Gerintya, S. (2018). Dalam 13 Tahun, 56 Kepala Daerah Jadi Terpidana Korupsi.

Harefa, A. (2004). Membangkitkan Etos Profesionalisme. Jakarta: Gramedia Pustaka Utama.

Hidayahtullah. (2010). Pendidikan Karakter Membangun Peradaban Bangsa. Jakarta: Gramedia Pustaka.

Ikhwan, A. (2019). Sistem Kepemimpinan Islami: Instrumen Inti Pengambil Keputusan pada Lembaga Pendidikan Islam. Istawa: Jurnal Pendidikan Islam. https://doi.org/10.24269/ijpi.v3i2.1503

Ikhwan, A. (2020). METODE PENELITIAN DASAR (Mengenal Model Penelitian dan Sistematikanya). Tulungagung: STAI Muhammadiyah Tulungagung. 
Kurniawan, A. (2005). Transformasi Pelayanan Publik. Yogyakarta: Pembaruan.

Meister, D. H. (1998). Profesionalisme Sejati. Jakarta: Gramedia Pustaka Utama.

Noor, A. F. (n.d.). Amanah.

Priyasmoro, M. R. (2018). 1.081 PNS Pemprov DKI Terlambat di Hari Pertama Kerja Usai Libur Lebaran.

Putri, W. T. A., \& Heriyudanta, M. (2021). Discussing Reframing Strategies for Learning Financial Literacy in Children. JIE (Journal of Islamic Education), 9(1), 82-100. Retrieved from https://ejournal.staim-

tulungagung.ac.id/index.php/edukasi/article/download/584/53 1

Roqib, M. (2013). PENDIDIKAN KARAKTER DALAM PERSPEKTIF PROFETIK. Jurnal Pendidikan Karakter, III(3).

Sedarmayanti. (2004). Membamgun Manajemen Sistem Kinerja Guna Meningkatkan Produktivitas Menuju Good Governance (Kepemerintahan yang Baik). In Good Governance (Kepemerintahan yang Baik). Bandung: Mandar Maju.

Siagian, S. P. (2009a). Administrasi Pembangunan. Jakarta: Bumi Aksara.

Siagian, S. P. (2009b). Kiat Meningkatkan Produktivitas Kerja. Jakarta: PT. Rineka Cipta.

Suseno, F. M. (1985). Etika Jawa Sebuah Analisa Falsafi tentang Kebijaksanaan Hidup Jawa. Jakarta: PT. Gramedia.

Suwinardi. (2017). Profesionalisme dalam Bekerja. ORBITH, 13(2), 81-85.

Tamrin, A. S., Rumapea, P., \& Mambo, R. (2017). PENGARUH PROFESIONALISME KERJA PEGAWAI TERHADAP TINGKAT KEPUASAN PELANGGAN PADA KANTOR PT. TASPEN CABANG MANADO. Jurnal Administrasi Publik, 3(046).

Tasmara, K. H. T. (2002). Membudayakan Etos Kerja Islami. Jakarta: Gema Insani Press.

Tongkrongan Islami. (2017a). Cerdas: Sifat Fathonah Nabi Muhammad SAW. Tongkrongan Islami. (2017b). Sifat Tabligh (Menyampaikan) Nabi Muhammad SAW. 